The concept of biodiversity and the history of conservation biology: from wilderness preservation to biodiversity conservation

O conceito de biodiversidade e a história da biologia da conservação: da preservação da wilderness à conservação da biodiversidade

\author{
José Luiz de Andrade FRANCO \\ University of Brasília, Brasília, Distrito Federal, Brazil \\ Contact: jldafranco@terra.com.br
}

\begin{abstract}
The essay deals with the emergence of the concept of biodiversity and with the rise of conservation biology as a subdiscipline of biology. It shows the relationship between conservation biology and the activism that develops with the objective of promoting biodiversity conservation. It refers to how, over time, in the field of concerns about the protection of natural heritage, there has been a shift from the notion of preservation of wilderness to the conservation of biodiversity.
\end{abstract}

Keywords: biodiversity; conservation biology; conservation of biodiversity.

Resumo: Trata do surgimento do conceito de biodiversidade e do processo de emergência da biologia da conservação como uma subdisciplina da biologia. Mostra as relações entre a biologia da conservação e o ativismo que se desenvolve com o objetivo de promover a conservação da biodiversidade. Discute como, ao longo do tempo, no campo das preocupações com a proteção do patrimônio natural, houve um deslocamento da noção de preservação da wilderness para a de conservação da biodiversidade.

Palavras-chave: biodiversidade; biologia da conservação; conservação da biodiversidade.

\title{
Introduction
}

This article discusses the emergence and significance of the concept of biodiversity and history of conservation biology. It intends to describe how research on taxonomy, ecology, evolution, behavior and distribution of species, allied to concerns about habitat destruction and species extinction, led to the emergence of conservation biology. It aims to understand the debate and intellectual context in which the concept of biodiversity was formulated, to conceive the diversity of ways in which life presents and organizes itself.

It deals with understanding how scientific speculation, aesthetic appreciation and ethical concerns merge in order to ensure the conservation of nature and, more specifically, the 
preservation of species, ecosystems, and gene pools. Scientists, scientific articles, books, and events important for the foundation and construction of conservation biology are presented throughout the text. The need for this field of biology to equate the demands of the "real world" (urgency to address the most immediate issues of activists, politicians, administrators, and technicians involved with the conservation of nature) and the theoretical and methodological requirements of the creation process of scientific knowledge are other points raised.

\section{The concept of biodiversity}

Although the perception of the variety of life forms is as old as the very self-consciousness of the human species (MAYR, 1998), the concept of biodiversity is quite recent. It was conceived by Walter G. Rosen, from the National Research Council/National Academy of Sciences (NRC/NAS) in 1985, while planning to conduct a forum on biological diversity. The event was held in the U.S. capital, Washington, from the $21^{\text {st }}$ to $24^{\text {th }}$ of September, 1986, with the name of the National Forum on BioDiversity, under the auspices of the NAS and the Smithsonian Institute (WILSON, 1997; SARKAR, 2002; MEINE, SOULÉ \& NOSS, 2006).

The forum took place at a time when interest in the knowledge of the diversity of life and concerns about its conservation, both among scientists and among a considerable portion of society, were taking momentum. The Society for Conservation Biology (SCB) was founded in 1985, and in 1987 the first issue of the journal Conservation Biology was published, which soon became the main vehicle for scientific publication and debate on issues related to biodiversity (SARKAR, 2002; GROOM, MEFFE \& CARROLL, 2006; MEINE, SOULÉ \& NOSS, 2006; LEWIS, 2007).

Exponents of the most varied fields of knowledge (biology, agronomy, economics, philosophy, among others), representatives of technical assistance and funding agencies, and nongovernmental organizations (NGOs) attended the National Forum on BioDiversity. The lectures and panels were attended by hundreds of people and had extensive press coverage. Above all, the issues revolve around the concern of the destruction of habitats and accelerated species extinction (WILSON, 1997).

Norman Myers, an English ecologist and environmentalist, in 1979 published the book The Sinking Ark: A New Look at the Problem of Disappearing Species. He discussed a familiar theme to ecologists: extinction. But, when drawing attention to its relationship with habitat destruction around the planet, especially the devastation of tropical forests, he alerted to the fact that the rate of the extinction of species was much higher than what would be expected in the course of the evolutionary process. Therefore, it dealt with a global crisis of species extinction, such as the one 
that decimated dinosaurs 65 million years ago. The difference now was that humans, and not a natural disaster, appeared as the major cause of the crisis. Myers argued that, by the year 2000, a million species would be extinct. It was a warning and a call for scientists to get into action (MYERS, 1979; LEWIS, 2007; QUAMMEN, 2004).

During the 1980s, the issue of the diversity of life was discussed as a research subject for scientists and as a matter of concern for activists and scientists. Actions to save species from extinction, especially the most charismatic species of fauna and flora - such as mammals, birds, magnificent trees, or plants with beautiful flowers - were not new. It was part of the tradition related to the creation of national parks and reserves, which, besides the preservation of the wild fauna and flora, was aimed at the protection of landscapes and geological features of great beauty. Therefore, the notion of "natural heritage" was quite appropriate and sufficiently ample. Terms like natural diversity or diversity of life were common when it came to alluding to the living components of nature, i.e., the diversity of organisms or species (MCCORMICK, 1992; NASH, 2001; LEWIS, 2007).

The term biological diversity appeared early in 1968 in the book A Different Kind of Country, authored by scientist and conservationist Raymond F. Dasmann. However, it was only in the 1980s that its use became more common in scientific jargon. It was Thomas Lovejoy, a biologist active in the World Wildlife Fund (WWF), in the preface to the collection edited by Michael E. Soulé and Bruce A. Wilcox, Conservation Biology: An Evolutionary-Ecological Perspective, in 1980, who rescued the term for the scientific community. Lovejoy, after warning the intensity of the impact of human actions on biological systems on the planet, argued that the reduction of biological diversity was the most fundamental question of our time (DASMANN, 1968; SOULÉ \& WILCOX, 1980).

Ernst Mayr, the reputed evolutionist, in his book The growth of biological thought: diversity, evolution, and inheritance, published in 1982, stated that: "Hardly any aspect of life is more characteristic than its almost unlimited diversity" (MAYR, 1998, p. 161, freely translated by the author). For him, the perception of diversity acts, throughout history, as the main force to drive biological thought: "Certainly, there is hardly a biological process, or a phenomenon, in which diversity is not involved" (MAYR, 1998, p. 161, freely translated by the author). The notion, observation, description, and contemplation of life's diversity, therefore, are not new, and its "trail" can be followed since the beginning of the biological sciences and activism for nature conservation (MEINE, SOULÉ \& NOSS, 2006).

Biodiversity is the contracted form of biological diversity and it first appeared in a publication in 1988, precisely in the book edited by renowned biologist Edward O. Wilson who 
brought the results from the National Forum on BioDiversity. The collection, with the title of

Biodiversity, ${ }^{1}$ is comprised by 60 articles written by leading international authorities on the subject, who were present at the forum, among which were Wilson himself, Paul R. Ehrlich, Norman Myers, David Ehrenfeld, Robert E. Jenkins, Thomas E. Lovejoy, Lester R. Brown, Michael Soulé, and James Lovelock. Apart from the initial chapter, written by Wilson, on the status of biological diversity, the remaining ones are divided into 12 topics related to the issue of biodiversity: Challenges to the Preservation of Biodiversity; Human Dependence on Biological Diversity; Diversity at Risk: Tropical Forests; Diversity at Risk: The Global Perspective; The Value of Biodiversity; How is Biodiversity Monitored and Protected?; Science and Technology: How Can They Help?; Restoration Ecology: Can We Recover Lost Ground?; Alternatives to Destruction; Policies to Protect Diversity; Present Problems and Future Prospects; and Ways of Seeing the Biosphere. There is also an Epilogue by David Challinor, Assistant Secretary for Research at the Smithsonian Institute, on the National Forum on BioDiversity and on how the book derives from the panels presented in it (WILSON, 1997; SARKAR, 2002).

In the preface of the book, Wilson alerted to the fact that:

The diversity of life forms, in such large numbers that we have yet to identify most of them, is the greatest wonder of this planet. The biosphere is an intricate tapestry of life forms that are intertwined. [...] This book provides an overview of this biological diversity and brings an urgent warning that we are altering and destroying the environment that created the diversity of life forms for over a billion years (WILSON, 1997, freely translated by the author).

The National Forum on BioDiversity and the book Biodiversity were, at the same time, the end point and starting point for efforts related to nature conservation. They were a focal point for reflection on the knowledge accumulated through years of research on biological diversity and practices focused on the conservation thereof. The concept of biodiversity and the consensus among scientists and activists about the urgency of preventing biodiversity from continuing to be destroyed by the excesses of the human species led to a shift in the way we address the issue of nature conservation. From a concern with the preservation of wilderness, with its sublime landscapes and charismatic fauna and flora, there was a gradual transition to the concept of conservation of biodiversity or biodiversity conservation (NASH, 2005; LEWIS, 2007).

This shift did not suddenly occur, it had been occurring since, at least, the 1930s and 1940s. During this period, Charles Darwin's theories on evolution and natural selection of species were confirmed, which became known as the "grand synthesis", which made the views of field biologists and geneticists converge on how evolution and emergence of new species come about - Sewall 
Wright, R. A. Fisher, J. B. S. Haldane, Theodosius Dobzhansky, George Gaylord Hutchinson, and Ernst Mayr played a key role in the preparation of this intellectual synthesis. With this, the role of the evolutionary process in the emergence and extinction of species and the very concept of species became clearer. It was also from these two decades that the research in the field of ecology and the ecologists themselves began to play a greater role in matters related to the conservation of nature concepts formulated by ecologists such as Henry C. Cowles, Victor Shelford, Arthur Tansley, Charles Elton, Joseph Grinnell, Paul Errington, Olaus Murie, and the brothers Howard and Eugene Odum were applied, with increasing frequency to conservation. The emergence of the concept of biodiversity has provided a reference point from which research on the diversity of life and the discourses and practices for their conservation has been oriented (MAYR, 1998; MAYR, 2005; MAYR, 2008; EHRLICH, 1993; WORSTER, 1998; ACOT, 1990; MEINE, SOULÉ \& NOSS, 2006; QUAMMEN, 2004).

In scientific literature, the interchangeable terms of biological diversity and biodiversity emerged to account for issues related to fundamental topics of ecology and evolutionary biology, related to the diversity of species and with the environments that serve to support them, at the same time in which they are supported by it, they are, simultaneously, both the stage and the result always unfinished - of the evolutionary process. Biodiversity and biological diversity have become widely used in scientific circles and among conservation activists. Sarkar (2002) notes that, in 1988, biodiversity did not appear even once as a keyword in the abstracts of biology journals, whereas biological diversity appears only once. Back in 1993, he counts 72 appearances for biodiversity and 19 for biological diversity. He also calls attention to the emergence of four journals that contain the word biodiversity in its name: Canadian Biodiversity was the first, in 1991; Tropical Biodiversity was the second, in 1992; and Biodiversity Letters and Global Biodiversity came next, in 1993.

The notion of biodiversity or biological diversity remains rather vague, and the measurement of biodiversity in the "real world" is not an easy task. Wilson (1999), in 1992, in the book The diversity of life, indicated the species as the fundamental unit of biodiversity:

[...] the species concept is crucial to the study of biodiversity. It is the grail of systematic biology. Not to have a natural unit such as the species would be to abandon a large part of biology into free fall, all the way from the ecosystem down to the organism. It would be to concede the idea of amorphous variation and arbitrary limits for such intuitively obvious entities as American elms (species: Ulmus americana), cabbage white butterflies (Pieris rapae), and human beings (Homo sapiens). Without natural species, ecosystems could be analyzed only in the broadest terms, using crude and shifting descriptions of the organisms that compose them. Biologists would find it difficult to compare results from one study to the next. How might we access, for example, the thousands of research papers on the fruit fly, which form much of the foundation of modern genetics, if no one could tell one kind of fruit fly from another? (WILSON, 1999, p. 38). 
With the growing concern for the conservation of biodiversity, the United Nations Conference on Environment and Development, held in Rio de Janeiro in 1992, the Convention on Biological Diversity (CDB) was launched by the United Nations Environment Program (UNEP). A very broad and functional definition of biological diversity or biodiversity was reached at it, covering three levels: diversity of species, genetic diversity, and diversity of ecosystems.

The convergence between the use of the concept of biodiversity and the statement of conservation biology as a new discipline led to a new configuration of studies related to interaction, adaptation, emergence and disappearance of species of organisms. It also approached the scientific speculations and scientists themselves from everyday concerns of managers of protected areas and nature conservation activists. Daniel H. Janzen (1986), in the article The Future of Tropical Ecology, urged ecologists to undertake the necessary political activism for conservation. He expressed a mindset already widespread among ecologists, conservation biologists, taxonomists, botanists, and zoologists. Conservation biology has become the main arena for reflection and theoretical debate on issues related to conservation, and biodiversity its main focus (GROOM, MEFFE \& CARROLL, 2006; LEWIS, 2007; QUAMMEN, 2004).

\section{The History of Conservation Biology}

The major American textbook on conservation biology (GROOM, MEFFE \& CARROLL, 2006) presents this field of knowledge as a response from the scientific community to the impacts of humans on biodiversity and to a rate of species extinction that is now 100 to 1000 times above what would be normal (in the evolutionary process, species arise and disappear over time), i.e., a global biodiversity crisis:

[...] It is a relatively recent, synthetic field that applies the principles of ecology, biogeography, population genetics, economics, sociology, anthropology, philosophy, and other theoretically based disciplines to the maintenance of biological diversity throughout the world. It is recent in that it is a product of the 1980 s, although its roots go back centuries. It is synthetic in that it unites traditionally academic disciplines such as population biology and genetics with the applied traditions of wildlife, fishery, and land management and allied fields. It is most of all challenging and imperative, in that it is motivated by human-caused global changes that have resulted in the greatest episode of mass extinction since the loss of the dinosaurs 65 million years ago (GROOM, MEFFE \& CARROLL, 2006, p. 6). 
Whereas at the end of his book on habitat fragmentation, loss of biodiversity and conservation biology, David Quammen (2004) highlights the insight that Alfred Russel Wallace had in the distant Malay archipelago in the mid-nineteenth century, on the potential impacts of humans on the diversity of species that make up the natural world:

It seems sad that on one hand such exquisite creatures should live out their lives and exhibit their charms only in these wild, inhospitable regions, doomed for ages yet to come to hopeless barbarism; while on the other hand, should civilized man ever reach these distant lands, and bring moral, intellectual, and physical light into the recesses of these virgin forests, we may be sure that he will so disturb the nicely-balanced relations of organic and inorganic nature as to cause the disappearance, and finally the extinction, of these very beings whose wonderful structure and beauty he alone is fitted to appreciate and enjoy: This consideration surely tells us that all living things were not made for man (WALLACE apud QUAMMEN, 2004, pg. 610-611).

Beyond the threat that humans pose to the diversity of species, Wallace acknowledged what has become one of the key points of conservation biology: biodiversity was not made for humans nor by them. With this, the most varied forms of life earn "citizenship" as part of the concern for nature conservation. Not only species considered useful or beautiful, or the ecosystems considered agreeable and worthy of being admired as landscapes are valued. Biodiversity in all of its forms is considered important and carries an intrinsic value (GROOM, MEFFE \& CARROLL, 2006).

The concern with the erosion of biodiversity, the knowledge of its causes, and the actions that must be taken to stop it are main points to conservation biology. The causes of biodiversity loss are habitat destruction, invasive species, pollution, and over-exploitation (hunting, fishing, and gathering). Habitat destruction is currently the main cause for the disappearance of species. The perception by scientists that there is a relationship between the size and the variety of habitats and the number of species - species-area ratio - is one of the oldest and most fruitful generalizations of modern biology. The debates taking place around it, from the beginning of the twentieth century, are directly entangled with questions about the loss of species by the planet, where the wilderness area is fragmented and decreases each year (QUAMMEN, 2004; GROOM, MEFFE \& CARROLL, 2006; WILSON, 1999; WILSON, 2002; WILSON, 2008).

Although it is difficult to establish the exact moment in which the perception of species-area relationship first occurred, precursors as old as Johann Reinhold Forster, a naturalist who accompanied Captain Cook on his second voyage, in the second half of the eighteenth century, noted that islands had a greater or lesser number of species as its circumference was more or less extensive. H. C. Watson, in 1858, found that, when telling of the species of flora existing in $2.6 \mathrm{~km}^{2}$ of a rural region north of Surrey, in England, that there only half the total of all plants in Surrey 
could be found. Fifty years later, a researcher named Jaccard referred to the species-area relationship (QUAMMEN, 2004).

In the 1920s, a debate involving the Swedish botanist Olof Arrhenius and the American ecologist Henry Allan Gleason, who carried out experiments in artificially delineated lots such as sample areas from a larger area, led to the conclusion that larger areas sustain more species than smaller areas. The next step was taken by Philip Darlington who - in his research with beetles, conducted in the 1940s, on the islands of Cuba, Hispaniola, Jamaica and Puerto Rico - came to the conclusion that one island ten times smaller than another supports only half of the species of beetles that exist on the largest. Later, in 1957, he repeated this conclusion, now considering species of reptiles and amphibians, in his book Zoogeography. (DARLINGTON, 1957; QUAMMEN, 2004).

Between the late 1940s and early 1960s, Frank Preston established some of the most important concepts for the understanding of the species-area relationship. Among them are the "sample unit" - a group of species or a stretch of landscape that is part of a larger whole - and the "isolated unit" - a group of segregated species or an isolated part of the landscape, such as islands or fragments of remaining forests amidst landscapes dominated by agricultural crops. With the aid of a graph, Preston showed that a sample unit may only contain a portion of the species existing in a larger area. The equation $S=\mathrm{cA}^{\mathrm{z}}$, "famous" among conservation biologists, is also from him. " $\mathrm{S}$ " corresponds to the number of species, and " $A$ " is the size of the area. The values of "c" and " $\mathrm{z}$ " vary: "c", according to the taxonomic group and geographical region, and "z", according to the smoothest or most drastic degree with which the number of species decreases as the area decreases (PRESTON, 1948; PRESTON, 1962a; PRESTON, 1962b; NEKOLA; BROWN, 2007; QUAMMEN, 2004).

A series of sub-disciplines in biology, such as evolutionary biology, biogeography, taxonomy, ecology, demography of animal and plant species and genetics, associated with an increasing influence of the equations and mathematical models in biological research, converged in the publication, in 1967, of the book The Theory of Island Biogeography, a milestone for what ended up later as the sub-discipline of conservation biology. The book, authored by Robert $\mathrm{H}$. MacArthur and Edward O. Wilson, filled with mathematical formulas, shows that the number of species on any given island varies according to its area - area effect - and the distance from large land masses such as continents or even bigger islands - distance effect. In addition to explain the species-area relation very well, the book adds the distance factor. In it is shown that remote islands are home to fewer species, because they suffer the same amount of extinctions and receive fewer immigrants. It also brings the innovative concept of turnover, precisely to indicate the substitution 
of some species by others, maintaining a balance in the number of species. (MACARTHUR; WILSON, 2001; QUAMMEN, 2004; LOVEJOY, 2011).

The Theory of Island Biogeography was the result of a friendship, which begun in 1960, between MacArthur and Wilson. An article, published in the journal Evolution in 1963, preceded the book, An Equilibrium Theory of Insular Zoogeography. Together with the collaboration of MacArthur, Wilson promoted an experiment, carried out by a doctorate mentee, Daniel Simberloff, in the Florida Keys. They counted the species of insects on four islands of various sizes and with different distances from the mainland. Afterwards, they fumigated the islands with insecticide to eliminate insectivorous fauna. Over the years they repeated the counting of insects until they demonstrated the recovery of the balance in the number of species on each island. Simberloff's thesis led to three published articles, co-authored with Wilson: Experimental zoogeography of islands: Defaunation and monitoring techniques and Experimental zoogeography of islands: The colonization of empty islands, in 1969, and Experimental zoogeography of islands: A two-year record of colonization, in 1970 (MACARTHUR \& WILSON, 2001; WILSON \& SIMBERLOFF, 1969; SIMBERLOFF \& WILSON, 1969; SIMBERLOFF \& WILSON, 1970; WILSON, 1999; WILSON 1997a; QUAMMEN, 2004; LOVEJOY, 2011).

The early death of MacArthur in 1972, aged 42, of cancer, deprived biology of one of its most talented and brightest researchers. With a master's degree in mathematics from Brown University, he was, during his doctorate in biology, one of the beloved mentees of George Evelyn Hutchinson, an expert in limnology, who gained notoriety for promoting research that brought the concepts of evolutionary biology and the tools of mathematics to the study of ecology. MacArthur finished his thesis on the distribution of ecological niches among birds from the conifer forests of New York, in 1958. Throughout his academic life, he searched for patterns that could be perceived and outlined with the help of equations and mathematical models in the fields of evolutionary biology, biogeography and ecology. His last contribution was the book Geographical Ecology: patterns in the distribution of species, published in 1972 (MACARTHUR \& WILSON, 2001; MACARTHUR, 1972; WILSON 1997a; QUAMMEN, 2004; LOVEJOY, 2011).

Wilson, a field entomologist with a doctorate from Harvard, was already a recognized scientist in the 1960s for his work with ants - as a taxonomist and as an ecologist. In the 1970s, he became famous as the central character of controversies on sociobiology, especially with the publication in 1975 of his book Sociobiology: The New Synthesis. He is the prototype of a scientist, with an established academic career, which will, over time, become more and more engaged with issues from "the real world". The theory of island biogeography made Wilson a key figure in debates about nature conservation. As a renowned scientific authority, he assumed the role of 
The concept of biodiversity and the history of conservation biology: from wilderness preservation to biodiversity conservation

promoter and defender of the cause for conservation. From the 1980s, many of his books, written in a clear and fluid style, make the knowledge about the diversity of life, and the urgent need to protect it, more accessible. Among them: Biophilia, 1984; The diversity of life, 1992; The future of life, 2002; e The Creation, 2006. (MACARTHUR \& WILSON, 2001; WILSON, 2000; WILSON 1997a; WILSON, 1984; WILSON, 1999; WILSON, 2002; WILSON, 2008).

Many books by authors coming from the field of biology were important for the debate on nature conservation. It is worth mentioning the book by Raymond F. Dasmann, Environmental conservation, first published in 1959, with several revised editions, which played a key role among conservation activists. However, The Theory of Island Biogeography inspired a lot of research, debates and even the structure of a new field of biology: conservation biology. The theory of island biogeography, by MacArthur and Wilson, will be applied to explain the effects of habitat fragmentation and the various types of "insularity" present in the continents. This is what allows us to understand the size of its impact on the studies of ecology and biology of populations (DASMANN, 1976; MACARTHUR \& WILSON, 2001; WILSON 1997a; QUAMMEN, 2008; GROOM, MEFFE \& CARROLL, 2006; QUAMMEN, 2004).

While in 1968, Daniel H. Janzen published an article called Host plants as islands in evolutionary and contemporary times, S. David Webb, in 1969, published Extinction-origination equilibria in late Cenozoic land mammals of North America. David C. Culver and François Vuilleumier published, em 1970, respectively, the articles Analysis of simple cave communities, part I: Caves as islands, and Insular biogeography in continental regions (JANZEN, 1968; WEBB, 1969; CULVER, 1970; VUILLEUMIER, 1970; QUAMMEN, 2004).

James H. Brown published, in 1971, a seminal article, Mammals on mountaintops: Nonequilibrium insular biogeography. In it, Brown shows that the "islands", the mountainous peaks covered by forests in the desert of the Great Basin, in the western United States, proved the area effect of the theory of island biogeography - mountain peaks with larger areas had a greater diversity of mammals. The distance effect, however, was null. Forest fragments simply did not receive the migration of new species of mammals, there was no turnover, the extinctions were not compensated. The paper's conclusions indicated the path for future applications of the theory of island biogeography to issues related with habitat fragmentation and the loss of species (BROWN, 1971; QUAMMEN, 2004). This trend had already been predicted by MacArthur and Wilson in the first chapter of The Theory of Island Biogeography: 
in lesser or greater degree to all natural habitats. Consider, for example, the insular nature of streams, caves, gallery forest, tide pools, taiga as it breaks up in tundra, and tundra as it breaks up in taiga. The same principles apply, and will apply to an accelerating extent in the future, to formerly continuous natural habitats now being broken up by the encroachment of civilization [...] (MACARTHUR \& WILSON, 2001, pg. 3-4).

Jared Diamond, an ornithologist who made New Guinea his field of research, witnessed the destruction and fragmentation of forests that had occurred there. He worried about and accompanied the same process for other forests in places such as the Amazon, Central America, Africa, Madagascar, Malaysia, the Philippines, and Indonesia. He knew that the Barro Colorado Island, in Panama, a piece of land that was insularized with the construction of the canal, had lost much of its original fauna. The same could happen in any fragment of habitat that was not large enough to support all the species in equilibrium. Therefore, small fragments would support a smaller number of species than a large and continuous range of habitat. A new balance had to be established at a lower level. Diamond gave a name to this: relaxation to equilibrium. These ideas were exposed in two articles: Biogeographic kinetics: Estimation of relaxation times for avifaunas of Southwest Pacific islands, published in 1972 in Proceedings of National Academy of Sciences and The island dilemma: Lessons of modern biogeographic studies for the design of natural reserves, published in 1975 in Biological Conservation (DIAMOND, 1972; DIAMOND, 1975; QUAMMEN, 2004).

In the 1975 article, Diamond stated that an isolated reserve in the recent period could involve, for a while, a number of species larger than its balanced number, but that these surplus species disappear by a process of relaxation to equilibrium. The pace of this process, according to him, was faster in the smaller reserves. He also noted that different species require different minimum areas to sustain a population increase. At the end of the article, thinking about the survival of the greatest number of species possible, Diamond suggests a number of principles for the planning of protected areas: large reserves are better than small ones; reserves closer together are better than those far apart; reserves grouped and linked together are better than those that are separated and arranged in a straight line; round reserves are better than elongated reserves (DIAMOND, 1972; DIAMOND, 1975; QUAMMEN, 2004).

The journal in which Diamond's article was published, Biological Conservation, edited in England, appeared in 1968. It was one more indicator of concern to biologists with the conservation of nature. Also, with the title Biological Conservation, David Ehrenfeld published, in 1970, a book that sought to define the profile, the scope and direction to be followed by a conservation science. He argued that the practice of conservation must have a firm scientific basis and that the new science of conservation which was emerging had to erect this base from dialogue between 
The concept of biodiversity and the history of conservation biology: from wilderness preservation to biodiversity conservation

researchers from various scientific disciplines (MEINE, SOULÉ \& NOSS, 2006; EHRENFELD, 1970).

An important event for the affirmation of a field of biology focused on the issues of conservation was the symposium held at Princeton in 1973, in honor of Robert MacArthur. Participating, besides George Evelyn Hutchinson and Edward O. Wilson, were ecologists who were becoming a reference for thinking about conservation, such as Jared Diamond, James Brown, Robert May, Edwin O. Willis and John Terborgh. The volume Ecology and Evolution of Communities, organized by Martin Cody and Jared Diamond, published in 1975, was one of the outcomes of the symposium. The final article of the book, authored by Wilson and Willis, who had studied the effects of fragmentation on birds of Barro Colorado for a long time, anticipated many of the conclusions about biogeography applied from the Diamond article published in Biological Conservation (CODY \& DIAMOND, 1975; QUAMMEN, 2004).

The year 1975 marked the convergence of views on the principles suggested by Diamond and on the application of the theory of island biogeography to conservation planning. Robert M. May and John Terborgh - another one who had been carrying out studies on Barro Colorado Island published articles reinforcing Diamond's conclusions. The former published, in Nature, an article under the title Island biogeography and the design of wildlife preserves, and the latter published Faunal equilibria and the design of wildlife preserves in a collection of texts on tropical ecology (MAY, 1975; TERBORGH, 1975; QUAMMEN, 2004).

Would a large reserve really be better than several small isolated reserves? The year 1976 marked the beginning of the SLOSS debate - single large or several small. Daniel Simberloff and Lawrence Abele sparked controversy with the article Island biogeography theory and conservation practice, published in the journal Science. They argued, above all, against generalizations, defending the idea that small isolated reserves could eventually contain more species than a single large one. It came down to a case by case review. The reactions were not slow. Also in 1976, the journal Science published a series of replicas and the rejoinder in a section titled Island biogeography and conservation: Strategy and limitations (SIMBERLOFF \& ABELE, 1976; DIAMOND et al, 1976; QUAMMEN, 2004).

The SLOSS debate continued until the end of the 1970s and into the 1980s. The articles came out in profusion: Gilpin and Diamond (1976), Abele and Patton (1976), Brown and KodrickBrown (1977), Simberloff (1978), Diamond (1978), Abele and Connor (1979), Connor and Simberloff (1979), Gilpin and Diamond (1980), Simberloff and Connor (1981), among others. Important arguments were listed from both sides, but there was no triumphal conclusion. The 
controversy was, however, a seminal effect, as it stimulated the conducting of research and the formulating of concepts.

Thomas Lovejoy, who followed the debate closely, proposed and conducted the largest research project aimed at understanding the effects of the dynamics of habitat fragmentation on the diversity of species: the BDFFP - Biological Dynamics of Forest Fragments Project. Lovejoy began to reflect on the project in 1976; however, the need for planning, financing and negotiations delayed the start of activities. The project was located in the Brazilian Amazon, near the city of Manaus, where farmers driven by tax incentives were felling the forest to raise cattle. With the help of researcher Herbert Schubart, the National Institute of Amazonian Research - INPA, and Maria Tereza Jorge Pádua, director of the parks and reserves sector of the Brazilian Institute for Forestry Development - IBDF, Lovejoy convinced farmers to cut the forest down leaving fragments of different sizes and with different distances between them. Lovejoy initiated the BDFFP with the assistance of Richard O. Bierregaard Jr, a friend from Yale who, like him, was strongly influenced by George Evelyn Hutchinson (WILSON, 1999; BIERREGAARD et al, 2001; QUAMMEN, 2004).

In the foreword of Lessons from Amazonia: The ecology and conservation of a fragmented forest, a collection of articles on BDFFP research results, Edward O. Wilson explains the project objectives:

The Biological Dynamics of Forest Fragments Project began in 1979 with a single, easily to understood focus. Its primary purpose was to access the effect of reduction in rainforest area on biological diversity, and particularly on the number of species of plants and animals in remnant patches. Working off the elementary theory of island biogeography, it asked: What is the rate of species extinction in the forest fragment as the size of fragment is varied? Would this local extinction rate slow and halt, so that the number of species equilibrates? And finally, what processes occur in the demography and interaction of species following a reduction in habitat area? (BIERREGARD et al, 2001).

The BDFFP has counted on the participation of several researchers over the years. It has enabled the advancement of knowledge about the effects of habitat fragmentation. Lovejoy coined the term decay to ecosystems to refer to the extinction of the species in fragmented habitats, which corresponds to Diamond's relaxation to equilibrium concept. Edge effects and deterioration of habitats in the fragments were also observed. Different researches, conducted with various taxonomic groups were developed. Besides the importance of the fragment areas in determining the amount of species that remained, it was found that the variety of habitats was critical to the diversity of species. Thus, small fragments, which constitute different habitats, could house different taxon species in a less demanding area. This was precisely the conclusion reached by Barbara Zimmerman and Richard Bierregaard in their research on frogs, carried out within the BDFFP. The 
The concept of biodiversity and the history of conservation biology: from wilderness preservation to biodiversity conservation

results were published in 1986, in the article Relevance of the equilibrium theory of islands biogeography and species-area relations to conservation with a case from Amazonia. (ZIMMERMAN \& BIERREGAARD, 1986; BIERREGARD et al, 2001; QUAMMEN, 2004).

The "other leg" of conservation biology was population biology. Paul R. Ehrlich, an ecologist concerned with human population growth and with species extinction, played a key role in its development and exerted a profound influence on two important names in the process of the emergence of conservation biology: Michael Soulé and Michael Gilpin. Besides them, William Newmark, Mark L. Shaffer and Ian Robert Franklin contributed heavily to the formation of conservation biology, all of them anxious to clarify issues related to the size of populations of endangered species and their viability. This included discussing the species-area relationship and the capacity of habitats in ensuring the requirements of the species studied. The problems raised mainly concerned the probability of survival of the species and the factors that could lead them to extinction (MEINE \& SOULÉ; NOSS, 2006; QUAMMEN, 2004).

Gilpin, a physicist with a doctorate in ecology, was strong in mathematics and computer programming. He showed a special interest in population genetics, by the interactions between predators and prey and the competition between similar species. During the SLOSS debate, he stood beside and became a partner of Diamond. Later, in the 1980s, he also collaborated with Soulé. Along with him, he contributed to the affirmation of the meta-population concept. The metapopulation studies relate to populations of the same species that inhabit areas more or less distant from each other. Individuals or groups of individuals in a population can migrate from one area to another. In the case of the extinction of a population and immigration from one group to occupy the area that was left empty, there is a turnover - note that in this case, unlike what happens in the theory of island biogeography, the turnover comes about with individuals of the same species. Gilpin and Soulé worked on the issue of minimum viable population and on the processes that lead to extinction. In a study sponsored by the United States Fish and Wildlife Service on populations of a subspecies of water snake, endemic to the Concho and Colorado Rivers in Texas, they used and refined the meta-population concept. It was a key concept in understanding the population dynamics in a fragmented world (GILPIN \& DIAMOND, 1976; GILPIN \& DIAMOND, 1980; SOULÉ \& GILPIN, 1986; GILPIN \& SOULÉ, 1986, QUAMMEN, 2004).

The doctoral thesis from Newmark, a graduate student in political science who became interested in ecology, played a key role in discussions about the extinction of species in fragments and the planning of protected areas. Through a study of America's national parks, he proved the decay of ecosystems in fragmented landscapes and some of the fundamentals of the equilibrium theory of island biogeography. Newmark's research was simple and well designed. He compared 
old lists with newer lists containing more species of mammals present in the national parks. It was easy to discover that, as the parks became fragments, isolated habitats, they lost species. The smaller the area, the more species are extinguished locally. The size of populations of species was determined by the area of habitat available, and the smaller the population size, the greater the threat of extinction. The conclusions of Newmark also pointed to the debate on minimum viable populations and their habitat requirements, although he did not deal directly with this issue (NEWMARK, 1986; NEWMARK, 1987; QUAMMEN, 2004).

Mark Shaffer, in the late 1970s, in his doctoral thesis on the populations of grizzly bears in the Yellowstone system (which includes the national parks of Yellowstone and Grand Teton and an extensive area around them), coined the concept of minimum viable population, "MVP". It dealt with defining what the minimum size of a given population of species able to survive for a long time, a century, with a very high probability, 95\%. Shaffer also ranked the causes that can lead small populations to extinction. It is due to deterministic factors - systematic pressures generated by human action - and stochastic factors - accidental disturbances of a demographic, genetic and environmental character. Shaffer's studies touched on an increasingly sensitive issue for biologists concerned with conservation: to know what the viable minimum is in a fragmented world (SHAFFER, 1978; SHAFFER, 1981; QUAMMEN, 2004).

Soulé can be considered as the grand architect of conservation biology. He gathered, throughout the 1980s in a series of events and publications, leading scientists involved in issues related to the conservation of biological diversity. His diplomatic nature and his capacity for cooperation allowed him to get closer the SLOSS debate contenders and initiate a fruitful discussion about how to actually apply the concepts developed by science to the problems of the "real world". His early research was quite specific and concerned the genetic basis of morphological variations in reptiles. Over time, he turned to the problems caused by the destruction and fragmentation of habitats, such as the genetic decay of small populations and extinction. In 1978, with the help of a doctorate mentee of him, Bruce A. Wilcox, Soulé organized a meeting of the First International Conference on Conservation Biology at the University of San Diego. Around 20 biologists presented papers, including Jared Diamond, John Terborgh and Paul Ehrlich (QUAMMEN, 2004).

As a result of the conference, Soule and Wilcox gathered articles from participants in a volume entitled Conservation Biology: An evolutionary-ecological perspective. The book, prefaced by Thomas Lovejoy (as noted earlier, on the topic about the concept of biodiversity), had a first chapter by Soulé and Wilcox, Conservation Biology: Its scope and its challenge, in which they sought to trace the profile of the new discipline, and a final chapter signed by Paul Ehrlich, The Strategy of Conservation, 1980-2000, in which he indicated the routes to be followed to save the 
threatened species and ecosystems. The book is a landmark, considered by many as the foundation of the discipline of conservation biology. For the first time, a group of scientists who had consolidated their academic career under the influence of the theory of island biogeography and population biology were gathered in a publication that had the explicit aim of discussing the "decay of biological diversity" and "the rampant pace of habitat destruction":

In the lifetime of many who read this book, the relentless harrying of habitats, particularly in the tropics, will reduce rain forests, reefs and savannas to vulnerable and senescent vestiges of their former grandeur and subtlety. But loss of habitat and loss of species is not the whole disaster. Perhaps even more shocking than the unprecedented wave of extinctions is the cessation of significant evolution of new species of large plants and animals. Death is one thing - an end to birth is something else, and nature reserves are too small [...] to gestate new species of vertebrates $[\ldots]$. There is no escaping the conclusion that in our lifetime, this planet will see a suspension, if not an end, to many ecological and evolutionary processes which have been uninterrupted since the beginnings of paleontological time.

We hope it is only a suspension - that the horrible onslaught can be stopped before the regenerative powers of ecosystems are also killed. [...] This is the challenge of the millennium. For centuries to come, our descendants will damn us or eulogize us, depending on our integrity and the integrity of the green mantle they inherit (SOULÉ \& WILCOX, p. 8).

At the end of the 1970s, Soulé and Ian Franklin, a quantitative geneticist biologist, were struggling with the same question: how rare is too rare? The two of them had an approach that favored the problems posed by genetics. The two of them wrote chapters about the topic for Conservation Biology: An evolutionary-ecological perspective. Although they did not use Shaffer's term, "MVP", which later became widespread, that is what it was about. Franklin discussed problems like inbreeding depression and genetic drift in very depleted populations. It is what came to be known as "Rule 50/500": 50 was the number of individuals sufficient to avoid inbreeding or consanguinity in the short term and 500 was the minimum number to guarantee adaptability. Another Franklin contribution was to establish the distinction between census population (total) and effective population (which is able to reproduce). The chapter written by Soule presented similar conclusions. Considering aspects such as inbreeding depression, loss of adaptability and the possibility of a significant disruption in the processes that lead to the evolution of large vertebrates, Soule arrived at the number of 50 individuals, the minimum to eliminate the immediate risk of inbreeding depression. The basic rule term, which led to the idea of the "rule of 50/500", is from him (SOULÉ \& WILCOX, 1980; QUAMMEN, 2004).

Conservation and Evolution, a book that grew out of a collaboration between Soulé and Otto H. Frankel, a recognized Australian geneticist, came out in 1981. The volume consolidated Soulé's 
concerns with the relationship between populations and the maintenance of gene pools that can achieve adaptation and evolution over time. An important article by Soulé, What we really know about extinction?, in which he lists 18 factors that may contribute to the extinction of species, appeared in 1983, in another book on genetic aspects and nature conservation, Genetics and Conservation, organized by Christine M. Schonewald-Cox, W. Lawrence Thomas, Bruce MacBryde and Steven M. Chambers (FRANKEL \& SOULÉ, 1981; SCHONEWALD-COX et al, 1983; SOULÉ, 1983; QUAMMEN, 2004).

Invited by Hal Salwasser, an ecologist who worked at the United States Forest Service and who wanted to understand how to maintain viable populations of native vertebrates in U.S. national forests, Soulé organized, in 1984, a workshop sponsored by the United States Forest Service and the United States Fish and Wildlife Service. The meeting brought together a small group of researchers on the issue of the viability of populations, including Gilpin, Shaffer and Schonewald-Cox. It dealt with discussing the viability of populations in the "real world", in protected areas and for defined species, that was the challenge. The works of this group created a new volume edited by Soulé, Viable Populations for Conservation. The book, published in 1987, was thick and loaded with formulas and mathematical charts. The articles sought to refine and adapt the concept of "MVP" and to demonstrate the possibilities of applying the population vulnerability analysis, "PVA". The findings drew attention to the risk of extinction of drastically reduced populations and the insufficiency of the amount and size of protected areas (SOULÉ, 1987; QUAMMEN, 2004).

Daniel Simberloff, a shrewd critic of many of the generalizations of the equilibrium theory of island biogeography, was also skeptical of the "magic" numbers of population biology: the "rule of 50/500". He, however, did not stop to worry about the issues related to the destruction and fragmentation of habitats and the extinction of reduced populations. His point was that, to solve the problems of the "real world", case studies and the application of the theory in specific contexts were necessary. He argued that, although large reserves were fundamental, many small reserves fulfilled an important role. If they are scattered, they could be representative of a considerable amount of ecosystems and preserve relevant and unique species. In Belize, Alan Rabinowitz had proved that it was possible to ensure a viable population of jaguars (Panthera onca) in not a very large area. Simberloff worried about the fact that the major theoretical generalizations could come to derail conservation projects of small areas and the salvation of species with very reduced populations. Soulé, after meeting Simberloff casually when they were on a visit to Moscow, proposed a collaboration. In 1986, they both published, in the journal Biological Conservation, the article What do genetics and ecology tell us about the design of nature reserves? They emphasized the "keystone species" - those that play a crucial role in maintaining the cohesion of ecosystems over time - and 
The concept of biodiversity and the history of conservation biology: from wilderness preservation to biodiversity conservation

ensuring population viability. These aspects were considered by them essential for the planning of protected areas. (RABINOWITZ, 2000; SOULÉ \& SIMBERLOFF, 1986; QUAMMEN, 2004).

The years 1985, 1986, 1987 and 1988 were of great importance for the statement of conservation biology. In 1985, Soulé published the article What is Conservation Biology: A new synthetic discipline addresses the dynamics and problems of perturbed species, communities and ecosystems. He defines conservation biology as a discipline guided by a sense of mission or crisis, whose goal is to provide the principles and tools necessary to ensure the conservation of biological diversity. Also In 1985, Soulé promoted the Second International Conference on Conservation Biology, held in the city of Ann Arbor, with the support of the University of Michigan. In the organizing committee were William Conway, Paul Ehrlich, Lynn Greenwalt, David Hales, Thomas Lovejoy, Peter Raven, Daniel Simberloff and John Terborgh. Among those attending were Hal Salwasser, Norman Myers, Jared Diamond and Michael Gilpin. During the conference, as its main result, the Society for Conservation Biology (SCB) was founded, on May 8. (SOULÉ, 1986; SOULÉ, 1987a; MEINE, SOULÉ \& NOSS, 2006; QUAMMEN, 2004).

Another result of the Second International Conference on Conservation Biology was the publication in 1986 of another collection edited by Soulé, Conservation Biology: The Science of Scarcity and Diversity. In the first chapter, written by Soulé, Conservation Biology and the "Real World", conservation biology is defined, again, as a crisis discipline, from which it is often necessary to act before there is absolute confidence in the data, because the risks of no action, in general, are larger than those of inappropriate action. The structure of the book in six sections - The Fitness and Viability of Populations; Patterns of Diversity and Rarity: Their Implications for Conservation; The effects of Fragmentation; Community Processes; Sensitive Habitats: Threats and Management; Interacting with the Real World - sought to give an account of the main themes of conservation biology. Among the authors of the articles were big names like Soulé himself, Michael Gilpin, Thomas Lovejoy, Richard Bierregaard, Anthony Rylands, Daniel Janzen, John Terborgh, Norman Myers, Jared Diamond and Arne Naess - The inspirational philosopher of Deep Ecology. The articles were thick and contained case studies that brought contributions to the "real world" (SOULÉ, 1986; QUAMMEN, 2004).

As we have seen, the National Forum on BioDiversity was held in 1986, another event in which the focus was the concern over the destruction of habitats and the global crisis of species extinction. The collection organized by Edward Wilson, Biodiversity, which resulted from the forum, fits in perfectly within the emerging conservation biology. It was affirmed as a discipline applied to monitoring and troubleshooting related to the conservation of biodiversity, at all levels: ecosystems, species and gene pools. In May 1987, the first issue of the journal Conservation 
Biology was published under the auspices of the SCB, and it soon became the main vehicle for scientific communication and debate on biodiversity. SCB holds, also from 1987 on, annual meetings among practitioners of conservation biology (WILSON, 1997; SOULÉ, 1987a; SARKAR, 2002; GROOM, MEFFE \& CARROLL, 2006; MEINE \& SOULÉ; NOSS, 2006; LEWIS, 2007).

Conservation biology had emerged. The research and publications multiplied. Not only taxonomists, ecologists, evolutionists, biogeographers, behavioral biologists, population biologists and geneticists were worrying about issues related to conservation biology, but research and specific training in conservation biology programs began to emerge. Affiliations to the SCB and the number of participants at the annual meetings more than tripled between 1987 and 1991. Two large conservation biology manuals appeared in the 1990s: Essentials of Conservation Biology, by Richard B. Primack, in 1993, and Principles of Conservation Biology, by Gary K. Meffe and C. Ronald Carroll in $1994 .^{2}$ (PRIMACK, 1993; MEFFE \& CARROLL, 1994; SARKAR, 2002; GROOM, MEFFE \& CARROLL, 2006; MEINE, SOULÉ \& NOSS, 2006; LEWIS, 2007).

Increasingly, some publications mark the approach of conservation biology with issues related to the monitoring, management and restoration of biodiversity. Reed F. Noss and Allen Y. Cooperrider published Saving Nature's Legacy: Protecting and Restoring Biodiversity, in 1994. In 1998, Katrina Brandon, Kent H. Redford and Steven E. Sanderson organized the collection Parks in Peril: People, Politics, and Protected Areas. Michael Soulé and John Terborgh organized a collection, published in 1999, to discuss the various scales in the conservation of biodiversity and the need for comprehensive planning: Continental Conservation: Scientific Foundations of Regional Reserve Networks. Terborgh published, also in 1999, Requiem for Nature. Terborgh, Carel van Schaik, Lisa Davenport and Madhu Rao organized, in 2002, the volume Making Parks Work: Strategies for Preserving Tropical Nature. In 2004, Anne E. Magurran published a book geared primarily for measuring and monitoring biodiversity: Measuring Biological Diversity (NOSS \& COOPERRIDER, 1994; BRANDON, REDFORD \& SANDERSON, 1998; SOULÉ \& TERBORGH, 1999; TERBORGH, 1999; TERBORGH et al., 2002; MAGURRAN, 2011).

Soulé has edited two books on research priorities in the field of conservation biology: Research Priorities for Conservation Biology, together with Kathryn A. Kohn, in 1989, and Conservation Biology: Research Priorities for the Next Decade, with Gordon H. Orians, in 2001. The list of publications for conservation biology could be much longer. However, it is worth including a final volume. In 2010, Navjot S. Sodhi and Paul Ehrlich organized another collection, with the significant title of Conservation Biology for All. This is a very accessible overview of the main guiding themes of the discipline, such as habitat conversion and human needs, climate change and biodiversity, conservation planning, research for conservation, ecosystem services, 
management of endangered species, extinction, fires, habitat fragmentation and invasive species (SOULÉ; KOHN, 1989; SOULÉ; ORIANS, 2001; SODHI; EHRLICH, 2010).

Conservation biology has become the major forum for discussion of issues related to habitat destruction and species extinction. Just as the practitioners of the discipline, besides producing knowledge, intend to operate in the "real world", conservation biology ends up embroiled in ethics, philosophy, economics and social sciences. It expands the scope of the concerns with conservation, attributing "citizenship" to species and ecosystems that are not so charismatic. It shows itself to be sensitive to cultural differences and to the needs of various social groups. But, above all, it is part of a tradition of appreciation of the transcendent character of natural heritage, i.e., it shares the perception that nature has an intrinsic value (GROOM, MEFFE \& CARROLL, 2006; MEINE, SOULÉ \& NOSS, 2006; QUAMMEN, 2004).

\section{From the Preservation of the Wilderness to the Biodiversity Conservation}

The tradition of preserving wilderness includes authors such as Henry David Thoreau and John Muir, extending to Aldo Leopold until ending up at deep ecology by Arne Naess, George Sessions, and Bill Devall. It emphasizes the autonomy of wild nature, and its untamed and sublime aspect. The realization that the natural world was neither created by humans nor for humans leads to the assertion of its transcendental character and the assigning of an intrinsic value to it (MCCORMICK, 1992; NASH, 2005; WORSTER, 1998; WORSTER, 2008, LEWIS, 2007; LEOPOLD, s/d; SESSIONS, 1995; DEVALL \& SESSIONS, 2007).

Aldo Leopold (s/d) has joined the tradition of preserving wilderness with the more instrumental tradition of conservation of natural resources in his The Land Ethic. He argued for an expanded citizenship, in which humans appear as "fellow-voyagers with other creatures in the odyssey of evolution". He advocated "a sense of kinship with fellow-creatures; a wish to live and let live; a sense of wonder over the magnitude and duration of the biotic enterprise". (LEOPOLD, s/d, p. 109). It was inconceivable that an ethical relationship could "exist without love, respect, and admiration for land, and a high regard for its value. By value I of course mean something far broader than mere economic value; I mean value in the philosophical sense". (LEOPOLD, s/d, p. 223).

George B. Schaller, a student of animal behavior who initiated a series of field research related to the preservation of wildlife, upon describing his experience, explains well the trajectory and the dilemmas of many conservation biologists: 
Over the years I have evolved from biologist to conservation biologist: research enhances my role as an ecological missionary. The goal is to balance knowledge and action.

Conservation problems are social and economic, not scientific, yet biologists have traditionally been expected to solve them. Research is easy; conservation most decidedly is not. [...] Seldom clear-cut, environmental issues often involve moral ambiguity. Instead of being just a biologist, something for which I was trained, I must also be an educator, diplomat, fundraiser, politician, anthropologist... (SCHALLER, 2007, p. 24).

The way to address the issue of nature conservation changed. From the preservation of wilderness, with its sublime landscapes and charismatic flora and fauna, there was a shift towards the conservation of biodiversity. The urgency to prevent the destruction of biodiversity caused many biologists to become conservation biologists. The increasingly scientific focus, the need to deal with the issues of the "real world", especially those involving human interests, and the importance of managing, what in principle is untamed, the wilderness, has made biodiversity conservation one complex task. The transformations are accumulated and overlapped, but a thin line of continuity persists: the assigning of an intrinsic value for biodiversity, based more on an aesthetic sensitivity and on a sense of empathy for the diversity of life than in an unquestioned scientific knowledge.

\section{Bibliographic References}

ABELE, Lawrence \& PATTON, W. K. The size of coral heads and the community biology of associated decapod crustaceans. Journal of Biogeography, v. 3, 1976, p. 35-47.

ABELE, Lawrence; CONNOR, Edward F. Application of island biogeography theory to refuge design: making the right decision for the wrong reasons. In: LINN, R. M (Ed.). Proceedings of the First Conference on Scientic Research in the National Parks, v. 1. Washington, D.C.: U. S. Department of Interior, 1979.

ACOT, Pascal. História da Ecologia. Rio de Janeiro: Campus, 1990.

BIERREGAARD, Richard O. et al. Lessons from Amazonia: The ecology and Conservation of a Fragmented forest. Yale: Yale University Press, 2001.

BRANDON, Katrina; REDFORD, Kent H.; SANDERSON, Steven E. Parks in Peril: People, Politics, and Protected Areas. Washington - D.C./Covelo, California: Island Press/The Nature Conservancy, 1998.

BROWN, James H. Mammals on mountaintops: Nonequilibrium insular biogeography. American Naturalist, v. 105, n. 945, 1971, p. 467-478. 
The concept of biodiversity and the history of conservation biology: from wilderness preservation to

BROWN, James H.; KODRICK-BROWN, Astrid. Turnover rates in Insular Biogeography: Effect of immigration on extinction. Ecology, v. 58, n. 2, 1977, p. 445-449.

CODY, Martin; DIAMOND, Jared. Ecology and Evolution of Communities. Cambridge: Harvard University Press, 1975.

CONNOR, Edward F.; SIMBERLOFF, Daniel. The assembly of species communities: Chance or competition. Ecology, v. 60, n. 6, 1979, p. 1132-1140.

CULVER, David C. Analysis of simple cave communities, part I: Caves as islands. Evolution, v. 24, 1970, p. 463-474.

DARLINGTON, Philip. Zoogeography: The geographical distribution of animals. New York: John Wilwey \& Sons, 1957.

DASMANN, Raymond F. A Different Kind of Country. New York: MacMillan Company, 1968.

DASMANN, Raymond F. Environmental conservation. New York: John Wiley \& Sons, (Fourth edition), 1976.

DEVALL, Bill; SESSIONS, George. Deep Ecology: Living as if nature mattered. Salt Lake City: Peregrine Smith Books, 2007.

DIAMOND, Jared. Biogeographic kinetics: Estimation of relaxation times for avifaunas of Southwest Pacific islands. Proceedings of National Academy of Sciences, v. 69, n. 11, 1972, p. 3199-3203.

DIAMOND, Jared. The island dilemma: Lessons of modern biogeographic studies for the design of natural reserves. Biological conservation, v. 7, n. 2, 1975, p. 129-146.

DIAMOND, Jared et al; Island biogeography and conservation: Strategy and limitations. Science, v. 193, n. 4.257, 1976, p. 1027-1032.

DIAMOND, Jared. Niche shifts and rediscovery of interspecific competition. American Scientist, v. 66,1978, p. 322-331.

EHRLICH, Paul R. O Mecanismo da Natureza: O mundo vivo a nossa volta e como funciona. Rio de Janeiro: Campus, 1993.

EHRENFELD, David. Biological Conservation. New York: Holt, Rinehart \& Wilson, 1970.

GILPIN, Michael E.; DIAMOND, Jared. Calculation of immigration and extinction curves from the species-area-distance relation. Proceedings of National Academy of Sciences, v. 73, n. 11, 1976, p. $4130-4134$.

GILPIN, Michael E.; DIAMOND, Jared. Subdivision of nature reserves and the maintenance of species diversity. Nature, v. 285, 1980, p. 567-568. 
GILPIN, Michael E.; SOULÉ, Michael E. Minimun Viable Populations: Processes of species extinction. In: SOULÉ, Michael E. (Edited by). Conservation Biology: The Science of Scarcity and Diversity. Massachusetts: Michigan, 1986.

GROOM, Martha J.; MEFFE, Gary K.; CARROLL, C. Ronald (Eds.). Principles of Conservation Biology. 3. ed. Massachusetts: Sinauer Associates, 2006.

JANZEN, Daniel H. Host plants as islands in evolutionary and contemporary times. American Naturalist, v. 102, 1968, p. 592-595

JANZEN, Daniel H. The Future of Tropical Ecology. Annual Review of Ecology and Systematics, v. 17, 1986, p. $305-324$.

LEOPOLD, Aldo. A Sand County Almanac: And Sketches Here and There. New York: Oxford University Press, (first edition 1949), s/d.

LEWIS, Michael. Wilderness and Conservation Science. In: LEWIS, Michael (edited by). American Wilderness: A New History. New York: Oxford University Press, 2007, p. 205-261.

MACARTHUR, Robert H.; WILSON, Edward O. The Theory of Island Biogeography. New Jersey: Princeton University Press, 2001.

MACARTHUR, Robert H. Geographical Ecology: patterns in the distribution of species. New York: Harper \& Row, 1972.

MAGURRAN, Anne E. Medindo a Diversidade Biológica. Curitiba: UFPR, 2011.

MAYR, Ernst. O Desenvolvimento do Pensamento Biológico. Brasília: UnB, 1998.

MAYR, Ernst. Biologia, Ciência Única. São Paulo: Cia das Letras, 2005.

MAY, Robert M. Island biogeography and the design of wildlife preserves. Nature, v. 254, 1975, p. 177- 178.

MCCORMICK, John. Rumo ao Paraíso: A História do Movimento Ambientalista. Rio de Janeiro: Relume-Dumará, 1992.

MEFFE, Gary K.; CARROL, C. Ronald. Principles of Conservation Biology. Massachusetts: Sinauer Associates, 1994.

MEINE, Curt; SOULÉ, Michael; NOSS, Reed F. A mission $\square$ driven discipline: the growth of conservation biology. Conservation Biology, v. 20, 2006, p. 631-651.

MYERS, Norman. The Sinking Ark: A New Look at the Problem of Disappearing Species. Oxford, United Kingdom: Pergamon Press, 1979.

NASH, Roderick. Wilderness and the American Mind. Yale: Yale University Press, 2001.

NEKOLA, Jeffrey C.; BROWN, James H. The wealth of species: ecological communities, complex systems and the legacy of Frank Preston. Ecology Letters, vol. 10, 2007, p. 188-196. 
NEWMARK, William D. Mammalian richness, colonization, and extinction in Western American national parks. 1986. (PhD dissertation) - University of Michigan, 1986.

NEWMARK, William D. A land-bridge island perspective on mammalian extinctions in Western American parks. Nature, v. 325, 1987, p. 430-432.

NOSS, Reed F. \& COOPERRIDER, Allen Y. Saving Nature's Legacy: Protecting and Restoring Biodiversity. Washington - D.C./Covelo, California: Island Press/Defenders of Wildlife, 2004.

PRESTON, Frank W. The Commonness, and rarity, of species. Ecology, v. 29, n. 3, 1948, p. 254283.

PRESTON, Frank W. The canonical distribution of commonness and rarity - part I. Ecology, v. 43, 1962a, p. 185-215.

PRESTON, Frank W. The canonical distribution of commonness and rarity - part II. Ecology, v. 43, 1962b, p. 410-432.

PRIMACK, Richard B. Essentials of Conservation Biology. Sunderland, MA: Sinauer, 1993.

PRIMACK, Richard; RODRIGUES, Efraim. Biologia da Conservação. Londrina: E. Rodrigues, 2001.

QUAMMEN, David. The song of Dodo: island biogeography in an age of extinctions. New York: Scribner, 2004.

RABINOWITZ, Alan. Jaguar: One man's struggle to establish the world's first jaguar preserve. Washington - D.C./Covelo, California: Island Press/Shearwater books, 2000.

SARKAR, Sahotra. Defining “Biodiversity”, Assessing Biodiversity. The Monist, v. 85, n. 1, 2002, p. 131-155.

SCHALLER, George B. A Naturalist and Other Beasts. Tales from a life in the field. San Francisco: Sierra Club Books, 2007.

SHAFFER, Mark L. Determining minimum viable population sizes: A case study of the grizzly bear (Ursus arctos L.). 1978. (PhD dissertation) - Duke University, 1978.

SHAFFER, Mark L. Minimum population sizes for species conservation. BioScience, vol. 31, n. 2, 1981, p. 131-134.

SCHONEWALD-COX, Christine et al. (Edited by). Genetics and Conservation: A Reference Manual for Managing Wild Animal and Plant Populations. Menlo Park: Benjamin-Cummings, 1983.

SESSIONS, George. Deep Ecology for the 21st Century: Readings on the Philosophy and Practice of the New Environmentalism. Boston: Shambhala, 1995. 
SIMBERLOFF, Daniel; WILSON, Edward O. Experimental zoogeography of islands: A two-year record of colonization. Ecology, v. 51, 1970, n. 5, p. 934-937.

SIMBERLOFF, Daniel; WILSON, Edward O. Experimental zoogeography of islands: The colonization of empty islands. Ecology, v. 50, n. 2, 1969, p. 278-296.

SIMBERLOFF, Daniel; ABELE, Lawrence. Island biogeography theory and conservation practice. Science, v. 191, n. 4224, 1976, p. 285-286.

SIMBERLOFF, Daniel. Using island biogeographic distributions to determine if colonization is stochastic. American Naturalist, v. 112, n. 986, 1978, p. 713-726.

SIMBERLOFF, Daniel; CONNOR, Edward F. Missing Species Combinations. The American Naturalist, v. 118, n. 2, 1981, p. 215-239.

SODHI, Navjot S.; EHRLICH, Paul. R. Conservation Biology for All. New York: Oxford University Press, 2010.

SOULÉ, Michael E. \& WILCOX, Bruce A. (Edited by). Conservation Biology: An evolutionaryecological perspective. Massachusetts: Sinauer, 1980.

SOULÉ, Michael E.; FRANKEL, Otto H. Conservation and Evolution. New York: Cambridge University Press, 1981.

SOULÉ, Michael E. (Edited by). Conservation Biology: The Science of Scarcity and Diversity. Massachusetts: Michigan, 1986.

SOULÉ, Michael E. (Edited by). Viable Populations for Conservation. New York: Cambridge, 1987.

SOULÉ, Michael E. History of the Society for Conservation Biology: How and Why We Got Here. Conservation Biology, v. 1, n. 1, 1987a, p. 4-5.

SOULÉ, Michael E.; KOHM, Kathryn A. (Edited by). Research Priorities for Conservation Biology. Washington, DC: Island Press, 1989.

SOULÉ, Michael E.; TERBORGH, John (Edited by). Continental Conservation: Scientific Foundations of Regional Reserve Networks. Washington, DC: Island Press, 1999.

SOULÉ, Michael E.; ORIANS, Gordon H. (Edited by). Conservation Biology: Research Priorities for the Next Decade. Washington, DC: Island Press, 2001.

SOULÉ, Michael E. What we really know about extinction? In: SCHONEWALD-COX, Christnie et al. (Edited by). Genetics and Conservation: A Reference Manual for Managing Wild Animal and Plant Populations. Menlo Park: Benjamin-Cummings, 1983.

SOULÉ, Michael E. What is Conservation Biology: A new synthetic discipline addresses the dynamics and problems of perturbed species, communities and ecosystems. BioScience, v. 35, $\mathrm{n}$. 11, 1985, p. 727-734. 
SOULÉ, Michael E.; SIMBERLOFF, Daniel S. What do genetics and ecology tell us about the design of nature reserves? Biological Conservation, v. 35, 1986.

SOULÉ, Michael E. \& GILPIN, Michael E. Viability analysis for the Concho water snake, Nerodia hateri paucimaculata. Relatório apresentado ao U.S. Fish and Wildlife Service, Albuquerque, New Mexico, 1986.

TERBORGH, John. Requiem for Nature. Washington, DC: Island Press, 1999.

TERBORGH, John et al. Tornando os Parques Eficientes: Estratégias para a conservação da natureza nos trópicos. Curitiba: UFPR/Fundação O Boticário, 2002.

TERBORGH, John. Faunal equilibria and the design of wildlife preserves. In: GOLLEY, Frank B.; MEDINA, Ernesto. Tropical Ecological Systems: Trends in terrestrial and aquatic research. New York: Springer-Verlag, 1975.

VUILLEUMIER, François. Insular biogeography in continental regions. American Naturalist, v. 104, 1970, p. 373-388.

WEBB, S. David. Extinction-origination equilibria in late Cenozoic land mammals of North America. Evolution, v. 23, 1969, p. 688-702.

WILSON, Edward O. Biophilia. Cambridge: Harvard University Press, 1984.

WILSON, Edward O. (Org.). Biodiversidade. Rio de Janeiro: Nova Fronteira, 1997.

WILSON, Edward O. Naturalista. Rio de Janeiro: Nova Fronteira, 1997a.

WILSON, Edward O. The Diversity of Life. New York: W. W. Norton \& Company, 1999.

WILSON, Edward O. Sociobiology: The New Synthesis. Cambridge: Harvard University Press, 2000.

WILSON, Edward O. The Future of Life. New York: Vintage, 2002.

WILSON, Edward O. A Criação: como salvar a vida na Terra. São Paulo: Cia das Letras, 2008.

WILSON, Edward O.; SIMBERLOFF, Daniel. Experimental zoogeography of islands: Defaunation and monitoring techniques. Ecology, v. 50, n. 2, 1969, p. 267-278.

WORSTER, Donald. Nature's Economy: A History of Ecological Ideas. Cambridge: Cambridge University Press, 1998.

WORSTER, Donald. A Passion for Nature: The life of John Muir. New York: Oxford University Press, 2008.

ZIMMERMAN, Barbara L.; BIERREGAARD, Richard O. Relevance of the equilibrium theory of islands biogeography and species-area relations to conservation with a case from Amazonia. Journal of Biogeography, v. 13, n. 2, 1986, p. 133-143. 


\section{Notes}

${ }^{1}$ The book Biodiversity, organized by Edward O. Wilson, was published in 1988 by the National Academy Press, Washington. In this text, I use the translation from the Nova Fronteira publisher, 1997.

${ }^{2}$ The manual by Richard B. Primack has editions adapted to many countries, including Brazil, where the book was published with the title Biologia da Conservação, and Primack had Ephraim Rodrigues as coauthor. PRIMACK, Richard; RODRIGUES, Efraim. Biologia da Conservação. Londrina: E. Rodrigues, 2001. The Meffe and Carrol manual gained a revised and updated edition, in 2006, and a co-author, Martha J. Groom. Groom, Martha J.; MEFFE, Gary K.; CARROLL, C. Ronald (Eds.). Principles of Conservation Biology. 3. ed. Massachusetts: Sinauer Associates, 2006.

José Luiz de Andrade Franco holds a Ph.D. in History from the University of Brasilia (UNB). Associate Professor in the Department of History, the Post-Graduate Program in History and the Post-Graduate Program in Sustainable Development at UNB. Scholarship for Scientific Productivity from CNPq (National Research Council) - Level 2.

Received in September/2013.

Approved in November/2013. 